\title{
MONOPOLI ELEKTRONIK (ME 3IN1) UNTUK PEMBELAJARAN Di SEKOLAH DASAR NEGERI BANDUNGVREJOVSARI 3 MALANG
}

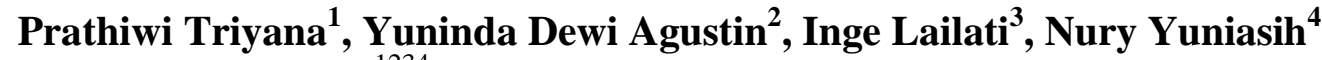 \\ ${ }^{1234}$ Universitas Kanjuruhan Malang \\ triyanaprathiwi@gmail.com
}

\begin{abstract}
This study aims to determine the effect of Electronic Monopoly (ME 3IN1) on the learning outcomes of 4th grade students at SDN Bandungrejosari 3. The approach used is quantitative research, with the type of quasi-experimental research. The IVA study sample was 27 students (control) and IVB class totaling 27 students (experimental). The research instrument used tests in the form of pre-test and post-test. based on the results of the study obtained a significance value of $0.00<0.05$ so that Ho was rejected Ha was accepted meaning that there was an influence of Electronic Monopoly (ME 3IN1) on student learning outcomes.
\end{abstract}

Keywords: Electronic Monopoly, ME 3IN1, Learning Outcomes

\begin{abstract}
Abstrak
Penelitian ini bertujuan untuk mengetahui pengaruh Monopoli Elektronik (ME 3IN1) terhadap hasil belajar siswa kelas 4 di SDN Bandungrejosari 3. Pendekatan yang digunakan adalah penelitian kuantitatif, dengan jenis penelitian eksperimen semu. Sampel penelitian IVA adalah 27 siswa (kontrol) dan kelas IVB berjumlah 27 siswa (percobaan). Instrumen penelitian menggunakan tes dalam bentuk pre-test dan post-test. berdasarkan hasil penelitian diperoleh nilai signifikansi $0,00<0,05$ sehingga Ho ditolak Ha diterima artinya ada pengaruh Monopoli Elektronik (ME 3IN1) terhadap hasil belajar siswa.
\end{abstract}

Kata Kunci: Monopoli Elektronik, ME 3IN1, Hasil Pembelajaran

\section{PENDAHULUAN}

Pembelajaran pada era digital saat ini difasilitasi dengan berbagai macam media elektronik. Terutama pada pembelajaran tematik kurikulum 2013 di sekolah dasar seluruh pembelajaran menggunakan buku elektronik dan guru wajib menguasai teknologi. Pembelajaran tematik memiliki karakteristik menerpadukan beberapa muatan pelajaran ke dalam sebuah tema, sehingga dalam satu pembelajaran saja siswa sudah mempelajari beberapa mata pelajaran. Setiap buku elektronik yang digunakan telah mencakup semua materi muatan pelajaran.

Berdasarkan hasil observasi yang dilakukan oleh peneliti di SDN Bandungrejosari 3 setiap pembelajaran guru mengunakan media power point untuk menjelaskan materi. Ketika guru menjelaskan siswa kurang antusias memperhatikan karena jenuh melihat 
tampilan power point yang penuh dengan kalimat. Isi dari power point tersebut yang berisi materi saja tidak ada gambar ataupun video yang dapat menarik perhatian siswa. Selain itu, apabila guru sudah menggunakan power point, guru cenderung menjelaskan melalui power point saja dan tidak menggunakan media lain yang menyenangkan sehingga siswa mudah lupa terhadap penjelasan guru. Kondisi ini menjadikan proses pembelajaran di dalam kelas menjadi tidak efektif. Materi pelajaran yang diberikan guru menjadi tidak dapat diterima dengan baik oleh siswa. Hal ini berakibat terhadap pengaruh hasil belajar siswa. Nilai siswa banyak yang belum mencapai KKM (Kriteria Ketuntasan Minimal). Oleh karena itu, guru perlu memberikan rangsangan yang tepat kepada peserta didik berupa penggunaan media pembelajaran yang tepat dengan karakteristik sikap siswa. Guru harus mampu memberikan media pembelajaran yang tepat agar siswa lebih aktif dan pembelajaran menjadi lebih bermakna.

Salah satu cara yang dapat digunakan untuk mengimbangi karakteristik siswa adalah dengan memberikan media yang di dalamnya terdapat permainan. Media tersebut salah satunya adalah media Monopoli Elektronik (ME 3IN1). Permainan monopoli adalah salah satu permainan papan yang cukup terkenal. Tujuan permainan ini adalah untuk menguasai semua petak di atas papan melalui proses menyewa, menjual dan membeli dengan prinsip ekonomi yang dibuat lebih sederhana (Husna, 2016).

Media Monopoli Elektronik ini dapat mencakup 3 fungsi yaitu sebagai media, permainan dan edukasi oleh karena itu media ini disebut ME 3IN1. Peraturan dalam media pembelajaran Monopoli Elektronik (ME 3IN1) memiliki kesamaan dengan permainan monopoli pada umumnya. Akan tetapi, pada media Monopoli Elektronik ( ME 3 IN 1 ) terdapat soal yang mencakup 1 tema yaitu tema 4 Berbagai Pekerjaan. Petak monopoli yang umumnya merupakan nama-nama negara diganti dengan pekerjaan di sekitar yang sesuai dengan pembelajaran yang diangkat. Selain itu, Monopoli Elektronik (ME 3IN1) memiliki keberbedaan yaitu berbasis kearifan lokal Malang sehingga siswa dapat mengenal lebih jauh mengenai budayanya. Jika pemain bukan dari warga Malang, maka dengan bermain Monopoli Elektronik (ME 3IN1) siswa akan mengetahui budaya Malang.

Berdasarkan (Suciati, Septiana, \& Untari, 2015) yang berjudul Penerapan Media Monosa (Monopoli Bahasa), melalui permainan dengan menggunakn media dalam 
pembelajaran dapat mendukung terciptanya rangsangan untuk meningkatkan kemampuan bahasa di Sekolah Dasar. Hasil penelitian yang telah dilakukan diperoleh data bahwa media pembelajaran Monosa sangat bagus dan sangat menarik. Media pembelajaran tersebut diharapkan dapat diterapkan dalam pembelajaran di SD dan mengaitkan dengan pembelajaran lain. Media pembelajaran yang dikembangkan sudah sesuai dengan pembelajaran SD yang menggunakan pendekatan tematik. Dengan penggunaan media pembelajaran tersebut diharapkan peserta didik tidak merasa jenuh atau bosan karena pembelajaran dilakukan dengan bermain.

Berdasarkan paparan di atas, tujuan penelitian ini adalah untuk mengetahui pengaruh monopoli elektronik (ME 3IN1) terhadap hasil belajar siswa kelas 4 di SDN Bandungrejosari 3.

\section{Pembelajaran Tematik}

Pembelajaran tematik sebagai suatu pendekatan belajar mengajar yang melibatkan beberapa mata pelajaran dalam satu tema untuk memberikan pengalaman bermakna bagi siswa.(Karli, 2016).

Menurut (Suciati, et al, 2016) pembelajaran tematik terpadu berfungsi untuk memberikan kemudahan bagi peserta didik dalam memahami dan mendalami konsep materi yang tergabung dalam tema serta dapat menambah semangat belajar karena materi yang dipelajari merupakan materi yang nyata (kontekstual) dan bermakna bagi peserta didik. Dengan demikian melalui pembelajaran tematik pembelajaran yang telah digabung dapat dilaksanakan dalam satu waktu sekaligus sehingga lebih efektif dan efisien. Karakteristik pembelajaran tematik yaitu :

1. Berpusat pada siswa (student cendered)

2. Memberikan pengalaman langsung pada anak

3. Pemisahan mapel tidak keliatan atau antar mapel menyatu

4. Bersifat fleksibel

5. Menyajikan konsep dari berbagai mapel dalam suatu proses pembelajaran sehingga bermakna

\section{MEDIA PEMBELAJARAN}

Media pembelajaran secara umum adalah alat bantu proses belajar mengajar. Segala sesuatu yang dapat dipergunakan untuk merangsang pikiran, perasaan, perhatian dan kemampuan atau ketrampilan pembelajar sehingga dapat mendorong terjadinya proses belajar. Media pembelajaran merupakan wahana penyalur pesan atau informasi belajar. (Nurseto, 2012). Terdapat dua jenis media pembelajaran meliputi media elektronik dan non elektronik:

a. Media Elektronik 
Media elektronik adalah media yang menggunakan elektronik atau energi elektromekanis bagi pengguna akhir untuk mengakses kontennya. Peneliti mengkhususkan membahas media elektronik karena peneliti akan menciptakan sebuah media pembelajaran yang berbasis elektronik yaitu Monopoli Elektronik (ME 3IN1).

\section{b. Media Non Elektronik}

Media non elektronik adalah media visual yang menyajikan fakta, ide atau gagasan melalui penyajian kata - kata, kalimat, angka, dan symbol/gambar, biasanya digunakan untuk menarik perhatian, memperjelas sajian atau ide, dan mengilustrasikan fakta-fakta sehingga menarik dan diingat orang.

Manfaat media pembelajaran sebagai berikut: (1) Menyamakan Persepsi Siswa. Dengan melihat objek yang sama dan konsisten maka siswa akan memiliki persepsi yang sama. (2) Mengkonkritkan konsep-konsep yang abstrak. Misalnya untuk menjelaskan tentang sistem pemerintahan, perekonomian, berhembusnya angin, dan sebagainya. bisa menggunakan media gambar, grafik atau bagan sederhana. (3) Menghadirkan objekobjek yang terlalu berbahaya atau sukar didapat ke dalam lingkungan belajar. Misalnya guru menjelaskan dengan menggunakan gambar atau video tentang binatang-binatang buas, gunung meletus, lautan, kutup utara dll. (4) Menampilkan objek yang terlalu besar atau kecil. Misalnya guru akan menyampaikan gambaran mengenai sebuah kapal laut, pesawat udara, pasar, candi, dan sebagainya. Atau menampilkan objek-objek yang terlalu kecil seperti bakteri, virus, semut, nyamuk, atau hewan/benda kecil lainnya. (5) Memperlihatkan gerakan yang terlalu cepat atau lambat. Dengan menggunakan teknik gerakan lambat (slow motion) dalam media film bisa memperlihatkan tentang lintasan peluru, melesatnya anak panah, atau memperlihatkan suatu ledakan. Dan juga gerakan-gerakan yang terlalu lambat seperti pertumbuhan kecambah, mekarnya bunga wijaya kusumah dan lain-lain. (Nurseto, 2012)

Media pembelajaran harus dibuat sedemikian rupa, agar menyenangkan dan tidak hanya dapat digunakan sebagai alat bantu untuk belajar, namun juga dapat digunakan untuk bermain agar siswa tertarik dan selalu termotivasi untuk belajar. Media pembelajaran menurut (Muhson, 2010) merupakan bagian dari sumber belajar yang merupakan kombinasi antara perangkat lunak (bahan belajar) dan perangkat keras (alat belajar). Sehingga 
media pembelajaran tidak hanya berupa benda nyata yang dapat dipegang, namun dapat juga berupa aplikasi yang dapat diprogram sesuai dengan kebutuhan kegiatan belajar mengajar.

Adapun menurut Djamarah dan Aswan (dalam Muhson, 2010: 3) mendefinisikan media sebagai alat bantu apa saja yang dapat dijadikan sebagai wahana penyalur informasi belajar atau penyalur pesan guna mencapai tujuan pembelajaran.

\section{Monopoli}

Permainan monopoli adalah salah satu permainan papan dan berkelompok yang sangat terkenal di dunia. Tujuan permainan ini menguasai semua petak melalui proses menyewa, menjual dan membeli dengan prinsip ekonomi yang dibuat lebih sederhana. (Husna, 2016)

Menurut (Suciati, et al, 2016) Media permainan monopoli merupakan salah satu media permainan yang dapat menimbulkan kegiatan belajar yang menarik dan membantu suasana belajar menjadi senang, hidup dan santai. Karena dalam monopoli banyak unsur-unsur yang dapat dilakukan oleh siswa dengan dikemas sedemikian rupa dalam bentuk permainan.

Setiap pemain melemparkan dadu secara bergiliran untuk memindahkan bidaknya, dan apabila ia mendarat di petak yang belum dimiliki oleh pemain lain, ia dapat membeli petak itu sesuai harga yang tertera. Bila petak itu sudah dibeli pemain lain, ia harus membayar uang sewa yang jumlahnya juga sudah ditetapkan.

Peralatan yang dibutuhkan untuk bermain monopoli antara lain;

1. Bidak-bidak untuk mewakili pemain

2. Dua buah dadu berisi enam angka

3. Kartu hak milik untuk setiap properti

4. Papan pemain dengan petak-petak

\section{ME 3IN1}

Monopoli Elektronik (ME 3IN1) adalah permainan monopoli yang dimainkan dengan menggunakan aplikasi Android dan di dalamnya terdapat tiga manfaat yaitu sebagai Media, Permainan, dan Pembelajaran. Monopoli ini dapat digunakan untuk media pembelajaran di kelas, selain itu juga untuk menambah wawasan tentang materi berbagai pekerjaan di lingkungan sekitar. Monopoli elektronik ini dapat di mainkan 2 sampai 4 orang, awal bermain pemain mendapatkan 15 bintang sebagai modal permainan. Lalu semua bidak pemain berada di petak berangkat, penentuan siapa yang akan main terlebih dahulu dikocok oleh sistem. Lalu pemain sesuai giliran mengocok angka dadu dan dadu otomatis berhenti pada petak sesuai angka dadu, apabila keluar angka dadu 6 maka pemain bermain lagi. Apabila 3 kali 
berturut-turut keluar angka dadu 6 maka pemain masuk ke petak hukuman. Apabila pemain sampai dari petak pekerjaan, pemain di perbolehkan membeli hak milik berupa alat pekerjaan, kartu kegiatan ekonomi atau tidak membelinya. Apabila sudah memiliki hak milik, jika pemain lain berhenti di pekerjaan anda maka dikenakan denda sesuai aturan pada kartu hak milik. Selain membeli kartu hak milik atau melewati saja, pemain harus membuka pertanyaan tersembunyi dari setiap petak, apabila tidak bisa menjawab loncat ke hukuman. Lalu apabila berhenti di petak dana umum atau kesempatan maka otomatis akan membuka kartu dana umum atau kesempatan. Pemain yang kehabisan bintang atau memiliki banyak hutang merupakan pemain yang kalah.

\section{Hasil Belajar}

Hasil belajar yaitu, perubahanperubahan yang terjadi pada diri siswa, baik yang menyangkut aspek kognitif, afektif, dan psikimotor sebagai hasil dari kegiatan belajar. Hasil belajar yang dicapai oleh peserta didik merupakan hasil interaksi antara berbagai faktor yang mempengaruhi baik faktor internal (bersumber dari dalam diri peserta didik), maupun faktor eksternal (berasal dari luar diri peserta didik). (Susanto, 2013)
Menurut (Anam, 2017), taksonomi dibuat untuk mengklarifikasikan tujuan pendidikan. Dalam hal ini, tujuan pendidikan dibagi menjadi beberapa domain, yaitu: kognitif, afektif dan psikomotorik. Dari setiap ranah tersebut dibagi kembali menjadi beberapa kategori dan sub kategori yang berurutan secara bertingkat.

\section{METODE PENELITIAN}

Pada siswa kelas 4 SD dibagi menjadi dua kelompok diberikan pretest. Kelompok pertama sebagai kelompok kontrol yang menggunakan pembelajaran seperti biasanya dari guru, sedangkan kelompok kedua sebagai kelompok eksperimen yang diberlakukan dengan berbeda dari kelompok kontrol yaitu dengan menggunakan media Monopoli Elektronik (ME 3IN1).

Tabel 1. Desain kuasi eksperimen

\begin{tabular}{|l|l|l|l|}
\hline Kelas & Pre Test & Perlakuan & Post Test \\
\hline A & O1 & X1 & O 2 \\
\hline B & O3 & X2 & O4 \\
\hline
\end{tabular}

\section{Keterangan :}
A : Kelompok Kontrol
B : Kelompok Eksperimen
O1 : Pre Test Kelas A
$\mathrm{O} 2$ : Post Test Kelas B
O3 : Pre Test Kelas B
O4 : Post Test Kelas B
X1 : Pembelajaran Konvensional 
X2 : Menggunakan media Monopoli Elektronik (ME 3IN1).

Populasi dalam penelitian ini adalah seluruh siswa SDN Bandungrejosari 3 kelas 4A dan kelas 4B, sedangkan sampel dalam penelitian ini adalah siswa kelas 4B SDN Bandungrejosari 3 yang akan diberikan perlakuan khusus menggunakan media Monopoli Elektronik (ME 3IN1).

Instrumen penelitian adalah suatu alat yang digunakan untuk mengukur fenomena alam maupun sosial yang diamati atau alat ukur dalam suatu penelitian (Sugiyono, 2013: 102). Tes yang digunakan dalam mengukur hasil belajar siswa berbentuk soal tes multiple choice yang terdiri dari pre test dan post test. Soal tes diberikan kepada semua sampel sesuai dengan konsep yang diberikan selama perlakuan berlangsung. Lembar tes digunakan untuk mengetahui hasil belajar siswa dalam penelitian ini. Lembar tes ini diberikan kepada sampel dan waktu pelaksanaan pengambilan data (penelitian) dilakukan sesuai dengan jadwal pelajaran di sekolah. Tes hasil belajar yang digunakan sudah diuji validitas, reliabilitas, taraf kesukaran dan daya beda soalnya.

\section{HASIL DAN PEMBAHASAN}

Hasil uji normalitas yang dilakukan pada 27 siswa di kelas 4A (kontrol), yaitu $0,145>0,05(\operatorname{sig} 5 \%)$ dan kelas 4B (eksperimen) yaitu $0,064>0,05(\operatorname{sig} 5 \%$ ). Sehingga hasil normalitas Monopoli Elektronik (ME 3IN1) menunjukkan bahwa Monopoli Elektronik (ME 3IN1) teridentifikasi normal.

$$
\text { Selanjutnya pada tahap uji }
$$
homogenitas, diketahui nilai sig. Based on mean untuk variabel hasil belajar adalah sebesar 0,670. Karena nilai sig. 0,670 > 0,05, maka dapat disimpulkan bahwa varians data hasil belajar pada siswa kelas 4A dan kelas 4B adalah homogen.Hasil uji hipotesis menunjukkan :

Tabel 2. Independent Samples Test

\begin{tabular}{|l|l|l|l|l|l|}
\hline \multirow{2}{*}{$\begin{array}{l}\text { Equal } \\
\text { Variances } \\
\text { assumed }\end{array}$} & \multicolumn{2}{|l|}{ t-test for equality of means } \\
\cline { 2 - 5 } & F & Sig & t-hitung & Sig (2-tailed) \\
\hline $\begin{array}{l}\text { Posttest Equal Variances assumed Equal } \\
\text { variances not assumed }\end{array}$ & 321 & 573 & -4602 & 000 \\
\hline
\end{tabular}


Berdasarkan tabel di atas, terlihat bahwa $t_{\text {hitung }}$ untuk posttest dengan Equal variances assumed adalah -4.602 dengan nilai Sig. 0,000 $<0,05$ maka $\mathrm{H}_{0}$ ditolak. Dengan demikian, dapat disimpulkan bahwa ada perbedaan yang signifikan pada rata-rata pestasi belajar siswa antara kelas kontrol dan kelas eksperimen.

Berdasarkan hasil temuan yang telah di lakukan bahwa permainan monopoli dapat memberikan pengaruh yang postif pada kegiatan pembelajaran Monopoli adalah salah satu permainan papan yang paling terkenal di dunia. Tujuan permainan ini adalah untuk menguasai semua petak di atas papan melalui pembelian, penyewaan dan pertukaran propeti dalam sistem ekonomi yang disederhanakan. Setiap pemain melemparkan dadu secara bergiliran untuk memindahkan bidaknya, dan apabila ia mendarat di petak yang belum dimiliki oleh pemain lain, ia dapat membeli petak itu sesuai harga yang tertera. Wulandari dan Sukrino menambahkan bahwa monopoli adalah satu permainan papan dan pemain berlomba untuk mengumpulkan kekayaan melalui satu pelaksanaan sistem permainan dengan memasukkan pertanyaan yang akan dijawab oleh peserta pemain.Monopoli juga merupakan suatu permainan papan dimana pemain berlombauntuk mengumpulkan kekayaan melalui aturan pelaksanaan permainan. Pada game monopoli ada beberapa langkah yang secara otomatis dijalankan apabila memasuki kondisi tertentu, seperti saat mengambil kartu kesempatan, maka langkah atau petunjuk yang tertera pada kartu kesempatan akan secara otomatis dijalankan.

\section{KESIMPULAN}

Monopoli Elektronik (ME 3IN 1) berpengaruh terhadap hasil belajar. karena Monopoli Elektronik (ME 3IN1), siswa menjadi lebih tertarik dan bersemangat dalam belajar, sehingga meningkatkan nilai dalam belajar. hal ini dapat diketahui dari hasil analisis data yang terbukti bahwa tingkat signifikansi sebesar $0,00<0,05$ artinya $\mathrm{Ha}$ diterima dan Ho di tolak. Dengan demikian, ada pengaruh monopoli elektronik (ME 3IN1) terhadap hasil belajar.

\section{DAFTAR PUSTAKA}

Anam, K. (2017). Pembelajaran Berbasis Inkuiri Metode dan Aplikasi. Yogyakarta: Pustaka Pelajar.

Arikunto, S. (2009). Prosedur Penelitian Suatu Pendekatan Praktik : Edisi Revisi 6. Jakarta: Rineka Cipta. 
Gafur.A. (2012). Desain Pembelajaran. Penerbit Ombak : Yogyakarta.

Husna M, (2016). Permainan Tradisional Indonesia: Untuk kreativitas, ketangkasan dan keakraban. Jakarta: Andi Publisher.

Karli, H. (2015). Penerapan Pembelajaran Tematik SD di Indonesia. EDUHUMANIORA:

Jurnal Pendidikan Dasar,2(1). https://doi.org/10.17509/eh.v2i1.275 $\underline{2}$

Muhson, A. (2010). Pengembangan media pembelajaran berbasis teknologi informasi. Jurnal Pendidikan Akuntansi Indonesia, 8(2). https://doi.org/10.21831/jpai.v8i2.94 $\underline{9}$

Nurseto, T. (2012). Membuat Media Pembelajaran yang Menarik. Jurnal Ekonomi Dan Pendidikan. https://doi.org/10.21831/jep.v8i1.706 Poerwadarminta. (1983). Model Pembelajaran Tematik Kelas Awal Sekolah Dasar. Jakarta : Puskur balitbang. Depdiknas 2006.

Suciati, S, Septiana, I, Untari, M. (2016). Efektivitas Media Monopoli Berbasis (MONOSA) dalam Pembelajaran Tematik Integratif di SD Kelas IV. Mimbar Sekolah Dasar, 3(2). https://doi.org/10.17509/mimbarsd.v3i2.4253
Suciati, S. (2015). Penerapan Media Monosa (Monopoli Bahasa) Berbasis Kemandirian dalam Pembelajaran di Sekolah Dasar. Jurnal Mimbar Sekolah Dasar. Vol. 2 No. 2 ISSN 175-188.

Suciati, S., Septiana, I., \& Untari, M. F. A. (2015). Penerapan Media MONOSA (Monopoli Bahasa) Berbasis Kemandirian dalam Pembelajaran di Sekolah Dasar. Mimbar Sekolah Dasar.

https://doi.org/10.17509/mimbar$\underline{\text { sd.v2i2.1328 }}$

Sugiyono. (2013). Metode Penelitian Kuantitatif Kualitatif dan $R \& D$. Bandung : Alfabeta.

Suharsini.A. (2013). Manajemen Penelitian. Jakarta : PT. Rineka Cipta.

Susanto, A. (2013). Teori Belajar dan Pembelajaran di Sekolah Dasar. Jakarta: Kencana Prenadamedia Group.

Susanto, A. (2013). Teori Belajar dan Pembelajaran di Sekolah Dasar. Jakarta: Kencana Prenadamedia Group

Widoyoko, E. P. (2013). Evaluasi Program Pembelajaran. Yogyakarta : Pustaka Pelajar. 
